\title{
ERRATUM
}

\section{Erratum to: Secukinumab is Efficacious and Safe in Hispanic Patients with Moderate-to-Severe Plaque Psoriasis: Pooled Analysis of Four Phase 3 Trials}

\author{
Sandra Adsit · Enrique Rivas Zaldivar · Howard Sofen • \\ Ignacio Dei-Cas · César Maldonado-García · Elkin O. Peñaranda · \\ Luís Puig · Xiangyi Meng · Todd Fox · Adriana Guana
}

Published online: June 6, 2017

(C) The Author(s) 2017. This article is an open access publication

Erratum to: Adv Ther

DOI 10.1007/s12325-017-0521-z

Unfortunately, the given name and family name of the co-author Dr. César Maldonado García were incorrectly published in the original publication. The correct given name and family name should read as 'César' and 'Maldonado-García', respectively.

The online version of the original article can be found under doi:10.1007/s12325-017-0521-z.

S. Adsit $(\bowtie)$

TCR Medical Corporation, San Diego, CA, USA

e-mail: sadsit@therapeuticsinc.com

E. R. Zaldivar

Dermos, Guatemala City, Guatemala

H. Sofen

UCLA School of Medicine, Los Angeles, CA, USA

I. Dei-Cas

Halitus, Buenos Aires, Argentina

C. Maldonado-García

Centro Dermatológico "Dr. Ladislao de la Pascua",

Mexico City, Mexico
Also Dr. César Maldonado-García's affiliation should read as follows:

C. Maldonado-García

Centro Dermatológico "Dr. Ladislao de la Pascua", Mexico City, Mexico

The original article has been corrected.

Open Access. This article is distributed under the terms of the Creative Commons Attribution-NonCommercial 4.0 International License (http://creativecommons.org/licenses/ by-nc/4.0/), which permits any noncommercial use, distribution, and reproduction in any medium, provided you give appropriate credit to the original author(s) and the source, provide a link to the Creative Commons license, and indicate if changes were made.

E. O. Peñaranda

Riesgo de Fractura S.A., Bogota, Colombia

L. Puig

Hospital de la Santa Creu i Sant Pau, Universitat

Autònoma de Barcelona, Barcelona, Spain

X. Meng · A. Guana

Novartis Pharmaceuticals Corporation, East Hanover, NJ, USA

T. Fox

Novartis Pharma AG, Basel, Switzerland 